\title{
SMON の本態と臨床
}

\author{
新潟大学神経内科 教授 \\ 椿忠雄
}

はじめに

本疾患は，昭和39年第61回本学会（前川係二郎会長） のシンポジウム「非特異性脳垐檤炎症」にとりあげられ たが，その後今日に至るまで数多くの研究業績が発表さ れている，疾患の発生から病因究明に至る道はきわめて 特異であり，医学史に残る一つの事件であるう。演者は この疾患の臨床, 病理, 疫学ならびに実験的研究を通じ て関与して来たので，主としてその経過に䢨つて報告す 亏.

\section{SMONの命名}

上記シンポジゥムで一つの臨床病理学的特徵を有する 特異な疾患がとり出された，われわれ（椿，豊倉，塚 越）はこれをSubacute Myelo-Optico-Neuropathy 呼え だが，これが今日の S MONの命名の始まりである.

\section{II. 臨床的特徵}

スモン調査研究協議会による臨床部断指針（昭和 40 年）に示されているごとくである.ただし，これは原因 不明の時点で作成されたことと，診断基準ではないこと に留意する要がある。演者は腹部症状の解析，ことに腹 部症状を欠如する例，また重症例の症候について付言す る. 重症例になると，運動障害，視力障害が前景に出る が，知覚障害は必ずしも高度にはならない，このため病 像がDevic病に類似し，本症発生の初期にはDevic病と誤 部された例がある。 むた，不随意運動，言語障害，精神 症状を呈する場合がある.

また，非定型例として祝力障害のみを主徵とする例が ある.

\section{II. 病理学的特徵}

われわれが上記シンポジッムで発表した主要病変は， 末梢神経，沓髄の後甞と側案，視神経の対称性で末梢 (distal) に变化の強い偽系統的変性 (pseudo-systemic degeneration)ということであつた。 また 1 例のみの検索 しか出来なかつたが，後根神経節で神経細胞の変性， capsule cellsの增殖，神経線維の脱蹎を認めた。さた， 最重症の 1 例では延䯣オリーブ核などの神経細胞变性を 認めた，上記の所見はその後多くの人々により確認され たが，また，網膜神経節細胞，交感神経節を含む末梢自 律神経系の変珄など重要な所見も見いだされた。

神経系以外の臓器にも多少の”変化が 報告されている が，神経系のそれに対比して軽度かつ恒常的でない。

\section{IV. 本症に対する感受性の検討}

本症患者には手術の既往歴をるつるのが多いことが知 られいてる.ところが，この一部は手術をうけて間もな く発病しているが，一部は手術後長期間を経て発病して いる．前者は手術による直接の影響が考えられたが（後 になつて術後投与されたキノホルムが原因であることが わかつたが，手術が誘因として働いた可能性も否定でき ない，後者はこれでは説明できない。

演者ら（近藤，椿）恃，本症に対する感受性を検討す るため, 患者 119名, 配偶者71名と，それの近親につい て虫垂切除，およびその他の事項を分析した，患者は一 般集団の約 8 倍多くの虫切をみ，女子にはとくに多い。 虫切は家族集積性で，患者にみられないときもとの同胞 に多い，虫切時の臨床像と年令は，らつうの急性蛙桨 のそれ等しい，その他の手術は多くない，この現象 は，SMONと虫垂炎（虫垂切除）を生じやすい体質に 共通点があるためと思われる．同じ外因に暴露された場 合，感受性の高いものが発病したものと思われる.

な括，この調査には，手術後間もなくSMONを多発 した外科病院は対象に加兄られていなかつた。

\section{V. 患者発生の実態}

重松によれば，昭和47年12月18日現在の患者数は，確 实例容疑例を合せて 9,324例である，最初の報告例は昭 和30年とされているが，演者は昭和25年に発病し，症状 は注添 S MONに一致すると思われる1例を病歷上発見 した，さらに興味あることは，片平らにより報告された 
昭和12〜13年に発症した S MON容疑例である. キノホ ルム原末をそれぞれ $45 \mathrm{~g}$ 之 $50.5 \mathrm{~g}$ 投与された後神経症状 を発現した 2 例であり，すでに死亡しているため診断を 確認することはできないが，病歷の記载でみる限り S M ON容疑の例である．演者も病歴を検討する機会があつ たが，キノホルム服用を䄯けた後腹痛が先行し，知覚障 害優位, 下半身障害優位, 左右対称性障害などを示し, SMONに一致する点が多い，昭和30年以前でもキノホ ルムが大量長期投与された場合には，SMONを否定し えない症例が出現することは重要である。

昭和30年以降，年と共に患者の年間発生数は增加した が，昭和44年に最高に達し，キノホルムの肘売停止， 使用見合わせの処置の行なわれた昭和 45 年 9 月以降激減 し, 今日に至つている.

\section{VL. キノホルム説と疫学的根処}

SMONの疫学的調查により，特定の地域汇多発する ことの泳か，同一家族，職場，病院なとにも多発しやす いことが示され，夏季に多い点などと合せて感染説が支 配的となつた。この時点においてい臨床的ならびに病理 学的に感染症を思わせる所見はなかつたが，いくつかの 病源体の検出の報告法出され，感染説の印象を強めた。

いつぼう，豊倉らの緑舌の研究から始まつた緑色物質 の追究は成果をあげ，昭和45年 6 月30日田村らはこれが キノホルムの鉄キレートであることを発表した．演者ら はこの直後より，SMONとキノホルムの関係を疫学的 に追究し，両者の密接な関係を認め，同年 9 月 5 日の第 34回日本神経学会関東地方会で, SMONはキフホルム 服用によつて和こる特異な神経疾患であらうと結諭し た. 演者ら (椿, 本間, 星) の当時の主張の主な根処を ここに再揭すると下記のごとくである. (1) 神経症状発 現前にキノホルムを服用したるのは S MONの97\%澾 する. (2) 神経症状の発現時期とキノホルム服用時期は 密接な関俰がある. (3) キノホルム1日服用量の多いる のは，比較的短期間の腿用で発病する場合がある. (4)

服用量と重症度にはある程度の相関があるごとくであ る. (5) 病院のキノホルム使用量の推移と患者発生頙度 の推移性関連がある. (6) 集団発生のため伝染を寲われ た病院の発生は，キノホルムをるつて詵明できる。 (す) 本邦キノホルムの販売量の推移は患者発生数の推移之上 く並行する. (8) 目別 1 人当りの販売量の多い県は S M ON発生率多い。

演者らの主張には当初批判的な意見が多からたが，そ
の後各施設で行なるれた研究は次第にキノホルム説を支 持するに至つた．演者らもその後さらに疫学的調査をつ つけ，キノホルム説では説明できないといわれた事実を 打ら破りつつある.

VII. キノホルム説に対する反論とそれに対する意見 (略)

\section{VIII. 小児SMON}

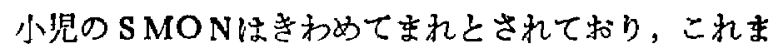
で文献にみられた報告例は7例にすぎず，井形らはをれ らのらち調查しえた 5 例が発病前にキノホルムを服用し ていた事実を明らかにした，演者らは4件の小児 SMO N患者を観察した. いずれる，キノホルムの服用後に発 症して括り，うち 1 例性acrodermatitis enteropathica, 1 例㤬疑似赤浰， 2 例《非特異的上思わ机る胃腸障害に対 して投与されたるのである.SMONの症状は成人とや や異なり，神経症状発現前の激しい腹痛を欠主，知覚障 害が軽く比較的治り易く，運動障害と視神経症状が比較 的出現し易い，小児 SMONがあれといわ机る反面には 成人之症状が多少異なるため診断し難いことも考愿すべ きである。しかし，われわれの調查では，小児にはキ， ホルムが長期投与されるこ上はをれであり，小児 SMO Nの頻度の少ない理由はこれで説明できる。この点では 井形らの成績と一致している.

\section{IX. 外国のSMON}

キノホルム説に対する反論の一つとして，欧州ではキ 八ホルムが大量使用されているのに何故 S MON患者 が多発しないかの問題がある。演者ら（溙, 井形) はこ の問題の解明のため, 昭和46年欧州諸国の調查を行な い，8例の S MON様症状の患者の情報をえた，投与量 は1日750〜 1,500mgのすのが多く, 神経症状発現まで の期間は 5 週間〜 8 年間であり, 本邦例に比して長期間 腿用後に発病したものである.

また，欧州に和けるキノホルムの各個人あての投与状 態子調查したが，1 日量 $600 \mathrm{mg}$ 以下，2 週間以内のもの が多く, SMONの発生状況の欧州と本邦との差はキ， ホルムの使用法の差異で説明することす可能ではある が，その他の理由があるか否かは，大量舆期使用例が注 とんどないため不明である.

その後，オーストラリアから 6 例, オランダから 4 例 のSMON㥞症状の症例が報告され，演者も米国におい て1例を発見した。いずれるキノホルムまなは類似構造 の薬物を投与された後に発症したるのである. 
これらの症状はSMONのそれと類似しているが，す でに山本によつて指摘されたように幾分異なつた病像と いうこともできる．以下にその概略をのべる．(1) 神経 症状無現前の潡しい腹痛を欠く（2)知賞障害が比較的 轻く治り易い：(3)運動障害と視神経症状が比較的出現 乙易い，以上の 3 点であるが，本邦の小先 SMONの特 微と共通するものである。.もつともSelbyの報告例は本 邦の成人 S MONに最も近い症状を星していた。

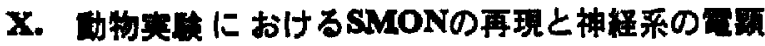 的研究}

キノホルムを動物に投与しSMONと同慊な病変を作 製する実験はキノホルム説を確証するために必要である が，立石らはネコ，雑犬，ビーグル犬を用い見事に成功 した.

演者らは同氏の方法にならいビーグル犬 8 頭，雑犬 4 頭にエンテロビオホルムを $20 \mathrm{mg} / \mathrm{kg} / \mathrm{day}$ から投与開始, 4 日ごとに渐增投与した，第 1 群（ビーグル犬 4 頭）は $100 \mathrm{mg} / \mathrm{kg} / \mathrm{day}$ 維持量として2 力月投与後, $300 \mathrm{mg} / \mathrm{kg} /$ dayに增量し，これを維持量とした，第2 群 (ビーダル 犬 4 頭）は $500 \mathrm{mg} / \mathrm{kg} /$ dayむで漸增，これを維持量とし たが，4 カ月後には少し減じ 400〜 450骂を稚持量とし た. 第 3 群（雑犬 4 頭） は漸增後 $300 \mathrm{mg} / \mathrm{kg} / \mathrm{day}$ 䧽持 量とした。雑犬はビーグル犬上りはるかに感受性が強く 180〜 280mg/kg/dayで 34〜54日目, 総投与量 3,240〜 $7,840 \mathrm{mg}$ で 全部発症，第 1 群は $300 \mathrm{mg} / \mathrm{kg} /$ dayで 120 日 目, 総投与量 $16,000 \sim 20,000 \mathrm{mg} て$ 発应，第 2 群は 440 $500 \mathrm{mg} / \mathrm{kg} /$ dayで80 104日目，総投与量 $20,240 \sim 28,000$ 讵で発症した.

病理学的所見では，雑犬はビーグル犬よりも变化が明 らかに高度であり，全例で末梢神経，Goll索，視神経に 变化があり，一部では錐体路に变化を来たしている. 網 膜の神程節細胞，奉䯣後根神経節細胞江著明な变化がみ られる. 軽症例でみると，後根神経節，Goll束，視神経 の順に障害されてゆくことが分かる.ビーダル犬゙では変 化の程度壮比校的俥いが，同様の变化がみられた：この 成経は立石のそれに一致し，またヒトのSMON所見と ஆ一致している.

電顕では，坐骨神経，上腕神経ともに近位部より遠位 部の神経線維の噵䩗の变化の強いものが多かつた，蹎鞘 の変化と同時に軸索の変化も認められ，両者同時に障害 されるよらな印象をらける．小径線稚より大・中径線維 が障害され易い，超微細構造の変化は，視神経，四肢の
神経にも共通して以下のごとくである．初期には随鞘層 粠造の離開，髄䩗一軸索問に小空胞が出現，次第に大き

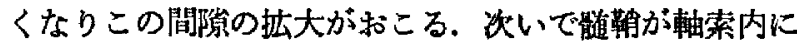
突出，谈入などをおこし，髉䩪の膨大と軸索の萎縮がみ られる。軸索も膨大するものがあり，とくにperikaryon の部におこり易い，膨大部ではneurofilamentが充満して いた，雑犬の坐骨神程では有陮線維にonion bulbの仅成 があり，然响線稚にも類似の所見を認めた。

\section{XI. 生体内におけるキノホルムの逐余とその作用}

共同研究者の滆橋らは，“Cキノホルムをラット腹整 内投与し, 各臟器内の放射能の分析を時間的経過とと もに観察したが，とりこみの高いものは肝，筒，血夜て あり，坐骨神経もかなりのとりこみを示す。大脳，小

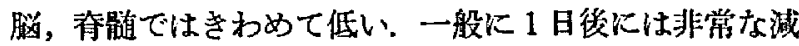
少をみるが，坐骨神経のみは7日後にもかなりのカウン

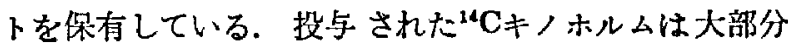
が24時間以内に层资とともに排泄され，以後少しずつ排 泄されるが，7日目には汪とんど排泄されない。

なお，キ/ホルム投与をうけたラットの坐骨神経の呼 吸はキノホルムの投与日数に比例して軽度であるが減少 しており，蛋白へのとりこみる，同時に測定された肝， 大䏚皮質とは異なり，軽度ではあるがやはり低下寸る俱 向がある.Schwann細胞の呼吸が坐骨神経の呼吸の ${ }^{2} / s を$ 占めるといわれるし，その蛋白合成活性も高いと考えら れているので何らかの関連を想定される.

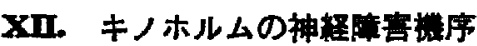

S MONおよびキノホルム慢性中毒動物の末梢神経， 視神経，春蹃長索路の変性はdying-back processと考え られる.

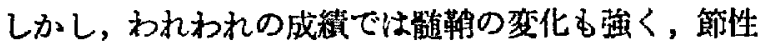
脱蹎を示す所見むあり，また末梢神経にとりこまれたき フホルムが艮く漌留している. 末梢神释を切断した遠位 部でも，全く同様にキノホルムがとりこまれる点よりみ

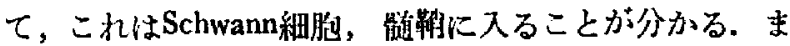
たSchwann稩胞の機能障害を推定させる事奏もある。 れらのことは，SMONが神経障害機序と企く然関係と 考えられず，これとdying-back processをどのように絬 びつけるかについて実験を行なつている.

われわれは S MONの後遗症状にA T P ・ニコチン酸 大量暆法が有効であることを発表したが，キノホルム がュニチン酸拮抗物質であるとの考市もあり，この関 連子考虑しなければならないが，SMONの神释病変は 
subacute combined degeneration とは異なり，単なるビ タミン久そ症とはいえない。

また，キノホルムのキレート作用が何らかの影響を及 ばしている可能性があり，キノホルム投与ラットの肝， 督，筋肉 $\mathrm{Mn}, \mathrm{Cu}, \mathrm{Zn}, \mathrm{Ca}, \mathrm{Mg}$ 变動を調べたが，とく にMnの含有量が急湤に低下し，腎呿よび等でも低下の 頃向があつたが，その意味づけは困難である。
xII. 予後および治庵

(略)

XIV. 桔語

演者はS MONのごく一面のみを述べたに過ぎない が，多くの研究者の協力でこれ程までに究明された疾患 はほとんどないとい方る，SMONにかんし不明な点は まだ多いが，これの解明される日も遠くないであるう。 